\title{
The Effect of Working Capital Turnover and Receivable Turnover on Profitability: Case Study on PT. Merck Tbk
}

\author{
Wiwiek Mardawiyah Daryanto ${ }^{1^{*}}$, Fajar Rachmanto ${ }^{2}$ \\ 1,2 Sekolah Tinggi Manajemen Ipmi, Jakarta 12750, Indonesia
}

\begin{abstract}
A B S T R A C T
With the growing world of business, the competition between similar companies getting tighter. To maintain the viability of a company required a good management of resources conducted by the management. Account Receivable turnover and working capital are very important for a company because it is the elements in measuring the profitability of the company. The purpose of this research is to know: (1) the effect of account receivable turnover to company profitability, (2) the effect of working capital turnover to the company, (3) the effect of account receivable turnover and working capital turnover to company profitability. The research method used is quantitative analysis, correlation coefficient test, the coefficient of determination test and hypothesis test. The data used in this study is secondary data sourced from financial statement PT. Merck Tbk period 2009-2013 obtained directly from the respondent. The results based on multiple linear regression tests showed that simultaneously turnover of account receivable and working capital turnover did not significantly affect company profitability $(5.603<9.55)$. Partially, the account receivable turnover does not significantly affect the profitability of the company $(2.298<3.182)$ and the working capital turnover does not significantly affect the profitability of the company $(3.003<3.182)$. So, it can be said the hypothesis in this study was rejected.
\end{abstract}

\section{ART I CLE INFO}

Keywords:

Working capital,

Account receivable,

Turnover,

Profitability
*Correspondent Email:

wiwiek.daryanto@ipmi.ac.id

Copyright ( 2017Authors. This is an open access article distributed under the Creative Commons Attribution License, which permits unrestricted use, distribution, and reproduction in any medium, provided the original work is properly cited.

\section{INTRODUCTION}

Account receivable turnover and working capital turnover is very important for a company because it is the elements in measuring the profitability of the company. Working capital is a short-term asset used by the company in operation to meet the needs of production, sales, distribution administration costs required before cash received from the sales of the company's finished products. Working capital is needed by every company to finance daily activities such as buying raw materials, paying salaries, 
paying debts, and paying other expenses. This working capital will continue to rotate every period within the company.

Working capital management should pay attention to several elements that make up the working capital such as the management of receivables. Effective and efficient working capital management will be a measure of a company's success in the company's own survival over the long term.

In the management of working capital, the management of accounts receivable should be considered well because the receivables also raise various costs for the company. Therefore, a method is used to assess whether the benefit of having receivables greater than or less than the cost. Accounts receivable arise when the company sells goods or services on credit. Receivables cover all debts in the form of debt to individual business entitles or other collectible parties. The process starts with making decisions to give credit to customers, delivering goods, billing and finally receiving payment.

An account receivable is an important part of the company because it is part of the current asset and always in a state of rotation. This means that the receivables can be used as cash immediately with the longest period of one year. But there is often an incorrect collection of account receivable at a predetermined time, while each company needs sufficient cash flow to play in the financing of the company's day-to-day operations and meet current liabilities on time.

If the account receivable increase, it means profitability of the company will increase also but at the same time the greater the risk that may occur on its liquidity. With the increasing proportion of credit sales from overall sales, will also increase the amount of investment in the form of receivables that can also increase the risk of non-payment of accounts receivable in the future. This happens because the sales of credit do not immediately generate cash, but it generates receivable subscriptions. Only later on the day of maturity occurs cash flow comes from the collection of accounts receivable.

Each company aims to gain profitability. Profitability is the company's ability to earn a profit. Profitability in the company aims to measure the company's financial performance, it needs a tool used to measure it. The tool used is financial ratios. Financial ratios include the profitability according to Syamsudin (2009:7275) are gross profit margin (GSM), operating profit margin (OPM), net profit margin (NPM), return on assets (ROA), return on investment (ROI), return on equity (ROE), return on common stock, earning per share (EPS), dividends per share, and book value per share. In this research, ROI is chosen as a tool to measure the company's ability to generate profitability with the overall amount of company assets.

This research aims to determine the effect of working capital turnover and a receivable turnover on profitability in PT. Merck Tbk period 20122016.

\section{LITERATURE REVIEW}

\section{Account Receivable Turnover}

Account receivable is company bills to other parties arising from the sales of products or services on credit that have not been received the settlement. accounts receivable company in normal activities will be repaid in less than one year, so they are classified as current assets. As for those included in this receivable only bills that will be paid off with money. Therefore, the delivery of goods to be deposited (consignment) is not recorded as receivable until the time the goods have been sold. While receivables arising from the sale of installments will be separated into current assets and not smooth depending on the period of the installment. If more than one year then it is not reported in the current assets group but entered into another assets group.

There are many kinds of account receivables owned by a company, but based on the types and origins of account receivables, within the company can be classified into two main groups, as stated by Rudianto (2009:225) as follows: 
1. Account Receivable are receivables arising from the sale of goods or services produced by the company. In normal business activities, accounts receivable will usually be paid off in less than one year, therefore account receivables are classified into current assets.

2. Non-trade receivables are receivables arising not as a result of the sale of goods or services produced by the company.

Account receivable turnover aims to know several times the receivables can be collected into the company. According to Munawir (2009:75) the formula used to calculate the turnover of receivable is as follows: Account Receivable Turnover = $\frac{\text { Credit Sales }}{\text { Average Receivable }}$

\section{Working Capital Turnover}

According to Horne and Wachowiez (2008:314) the concept of working capital there is two kinds, namely net working capital and gross working capital. The net working capital is the difference between current assets and current liabilities, while current liabilities are firm investments in current assets. A similar opinion is put forward by Keown (2010:644), that traditionally, working capital is the total investment of a company in current assets, while net working capital is the difference between current assets and current liabilities.

Regarding the types of working capital, Taylor (2010:223) categorizes into permanent working capital and variable working capital. Permanent working capital is working capital that must remain in the company to be able to perform its function, or in other words, working capital is continuously required for smooth business. Permanent working capital is divided into:

1. Primary working capital, ie minimum working capital that must remain in the company to ensure the continuity of its business.

2. Normal working capital, ie the amount of working capital required to carry out normal production area in a dynamic sense.

Variable working capital is working capital whose numbers vary according to changing circumstances. The working capital divided into:

1. Seasonal working capital, ie the changing amount of working capital caused by seasonal fluctuations.

2. Cyclical working capital, ie the amount of working capital that varies due to conjuncture fluctuations.

3. Emergency working capital, ie the amount of working capital that varies due to an unforeseen emergency.

Working capital is always in a state of operation or rotating within the company concerned in a business state. The working capital turnover period begins from the moment when cash is invested in the components of working capital until it is cash. The shorter the period means the faster the rotation or the higher the rotation. How long is the period of working capital turnover depending on how long the rotation of each component of the working capital. The formula used to measure working capital turnover is as follows: Working Capital Turnover $=\frac{\text { Net Sales }}{\text { Current Assets-Current Liabilities }}$

\section{Profitability}

Profitability is a measure of the percentage used to assess the extent to which a firm is able to generate profits at an acceptable level. Profitability figures are expressed among others in the rate profit before or after taxes, investment income, earnings, and profitsales.

To assess the profitability of a company that is with profitability ratios. This ratio measures the ability of firms to generate profit (profitability) at the level of asset sales and capital stock. There are several profitability ratios in accordance with interests of users of financial statements.

According to Hanafi (2007:83), there are several ratios to measure the level of profitability of the company, including:

1. Profit Margin: This ratio calculates the extent to which a company's ability to generate net income at certain sales levels.

2. Return on Investment (ROI): This ratio measures the company's ability to generate net income based on the level of corporate wealth. 
3. Return on Equity (ROE): This ratio measures the ability of firms to generate profits based on certain share capital.

In this research, profitability ratios used are to measures the ability of companies to generate profits based on the level of corporate investment.

\section{Return on Investment (ROI)}

Return on Investment (ROI) can be defined as a calculation that allows an attempt to determine the amount of business received from the investment of a certain amount of capital in the form of money or resources. The equation commonly used to calculate return on investment is as follows: Return on Investment $(R O I)=\frac{\text { Net Profit after Tax }}{\text { Total Assets }}$

\section{Research Framework and Hypotheses Development}

In this research, the factors that affect the profitability of the company, namely independent variable. In this research will be known whether the independent variable has a significant effect on the profitability of the company. The independent variables in this research are receivable turnover and working capital turnover. So, in this research will test whether the turnover of receivables and working capital turnover will significantly affect the profitability of the company.

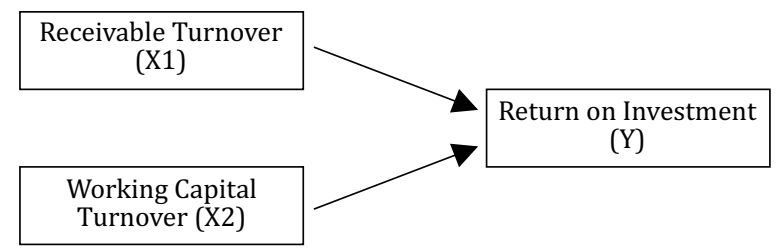

Figure 1. Research Framework

H1: Receivable Turnover affects Return on Investment of PT. Merck Tbk

H2: Working Capital Turnover affects Return on Investment of PT. Merck Tbk

H3: Receivable Turnover and Working Capital Turnover affects Return on Investment of PT. Merck Tbk

In the framework above shows that the path diagram there are two exogenous variables is turnover receivables and working capital turnover and one endogenous variable that is Return on Investment. In the diagram above suggests that the relationship between receivables turnover, working capital turnover and Return on Investment is a casual relationship.

\section{RESEARCH METHOD}

The data to be analyzed in this research relates to the relationship between the variables. Data analysis is done quantitatively with continued selection of statistical tests (ie multiple linear regression, T-test, and F-test), the goal is to determine whether the independent variable has a relationship with the dependent variable, determining the level of significant and ending with the basic research of drawing conclusions through acceptance or rejection of hypothesis.

Multiple linear analysis is used for states how big the rise and fall of the value of the variable depends on two or more independent variables. In addition, $\mathrm{F}$ test is also used to test the simultaneous hypothesis between the independent variables to the dependent variable on the multiple regression models. To test significant coefficient of multiple regression used $\mathrm{F}$ test with significantlevel $<0.05$.

Furthermore, T-test is used to test the regression coefficient by the partial influence of independent variable to dependent variable. This T-test is used to find out which independent variables are the most dominant its effect on the dependent variable. In multiple regression tested with a significant level $<0.05$.

\section{RESULT AND DISCUSSION Multiple Regression Analysis}

Multiple linear regression analysis is used to find out how the relationship between the two subvariables. In this case, variable receivables turnover with return on investment company. The followingthe results as follows: From the table 1. obtained multiple linear regression equations in this research are as follow: $Y=1.114-0.020 X 1-$ $0.248 X 2$. The regression equation shows that the turnover of receivables (X1) increases by $1 \%$ while other variables (working capital turnover) are considered constant then return on investment 
will decrease by 0.020 . Turnover of working capital (X2) increased by $1 \%$ while other variables (receivable turnover) are considered constant then return on investment will also decrease by 0.248 .

\section{T-test}

T-test is used to know whether or not a partially independent variable influence over a dependent variable. To test the hypothesis then first sought Tcount value, then compared with Ttable value. The hypothesis is as follows:

1. Ho: There is no significant influence between the independent variable and dependent variable (Ho accepted $\mathrm{Ha}$ rejected if Tcount<Ttable).

2. Ha: There is a significant influence between the independent variable with the dependent variable (Ho is rejected Ha accepted if the value of Tcount $>$ Ttable).

Table 2. Summary Result of T-test

\begin{tabular}{lccc}
\hline & Tcount & & Ttable \\
\hline Receivable Turnover & 2,298 & $<$ & 3,182 \\
\hline Working Capital Turnover & 3,033 & $<$ & 3,182 \\
\hline
\end{tabular}

Based on Table 1, Ttable calculations with significant level criteria of 0.05 and degrees of freedom $(\mathrm{dk})=\mathrm{n}-\mathrm{k}$ or $5-2=3$ (n is the number of observations and $\mathrm{k}$ is the number of independent variables), the Ttable is 3.182. Based on the value of T-test obtained, partially the effect of independent variables on the dependent variables is as follows:

1. Receivable turnover obtained Tcount amounted 2.298 and Ttable 3.182, then obtained Tcount $<$ Ttable or $2.298<3.182$ which means Ha rejected and Ho accepted, in other words, that there is no significant influence between the turnover of receivables with return on investment.

2. Working capital turnover is obtained Tcount of 3.033 and Ttable 3.182, then the result is Tcount $<$ Ttable or $3.033<3.182$ which means Ha rejected and Ho accepted, in other words, that there is no significant influence between working capital turnover and return on investment.

\section{F-test}

This test is intended to test the overall regression coefficient and to know the meaning of the independent variable relation together with the dependent variable. Hypothesis testing will use a significant level of $5 \%=0.05$.

Table 3. Result of F-test

ANOVA ${ }^{2} 2 \mathrm{www}^{2}$

\begin{tabular}{|l|c|c|c|c|c|}
\hline Model & $\begin{array}{l}\text { Sum Of } \\
\text { Squares }\end{array}$ & Df & $\begin{array}{l}\text { mean } \\
\text { Square }\end{array}$ & F & Sig. \\
\hline Regression &, 021 & 2 &, 011 & 5,603 &, $151^{\text {b }}$ \\
\hline Residual &, 004 & 2 &, 002 & & \\
\hline Total &, 025 & 4 & & & \\
\hline
\end{tabular}

a. Dependent Variable: Return_On_Invesment

b. Predictors: (Constant), Working_Capital_Turnover, Receivable_Turnover

The results of Table 3. shows the Fcount of 5.603, this value which will be the best test statistic to be compared with the Ftable value calculated by df1 (degrees free of the numerator) $=\mathrm{k}-1=3-1=2$ and $\mathrm{df} 2$ (degrees of denominator) $=\mathrm{n}-\mathrm{k}=5-3=2$ then obtained the Fcount $<$ Ftable or $5.603<9.55$ which means Ho accepted and Ha rejected, in other words, that simultaneously turnover receivables and working capital turnover no significant effect return on investment.

Table 1. Result of Multiple Regression Analysis

Coefficients $^{\text {a }}$

\begin{tabular}{|l|c|c|c|c|c|}
\hline \multirow{2}{*}{ Model } & \multicolumn{2}{|c|}{ Unstandardized Coefficients } & Unstandardized Coefficients & \multirow{2}{*}{ T } & \multirow{2}{*}{ Sig. } \\
\cline { 2 - 4 } & B & Std. Error & Beta & & \\
\hline Mo(Constant)del & 1,114 &, 250 & & 4,458 &, 047 \\
Receivable_Turnover &,- 020 &, 009 &,- 666 & $-2,298$ &, 148 \\
Working_Capital_Turnover &,- 248 &, 082 &,- 879 & $-3,033$ &, 094 \\
\hline
\end{tabular}

a. Dependent Variable: Return On Investment 


\section{Discussions}

According to the result of the partial test of the hypothesis that is the result of the test above, receivable turnover and working capital turnover does not have a significant effect on return on investment. This is evidenced by the significant value of receivable turnover and working capital turnover greater than 0.05 , then it can be concluded that Ho is accepted and Ha rejected.

In the F-test the results of the research stated that Fcount $<$ Ftable or $5.603<9.55$ which means Ho accepted and Ha rejected, in other words, states that simultaneously turnover receivables and working capital turnover PT. Merck Tbk has no significant effect on return on investment.

\section{CONCLUSIONS AND DIRECTION FOR FUTURE RESEARCH}

Based on the results of research conducted at PT. Merck Tbk, with data used in this study, can be concluded that:

1. Variable receivable turnover and working capital turnover simultaneously no significant effect on profitability (ROI) at PT. Merck Tbk period 2009-2013, because the results obtained Fcount $<$ Ftable or $5.603<9.55$ which means Ha rejected and Ho accepted.

2. Partially variable receivable turnover and working capital turnover no significant effect on the profitability (ROI) of PT. Merck Tbk period 2009-2013. The effect of receivable turnover on profitability (ROI) obtained Tcount $<$ Ttable or $2.298<3.182$ ad influence of working capital turnover to profitability (ROI) obtained by Tcount $<$ Ttable or $3.033<3.182$. From these results can be interpreted as both variables partially result in Ha rejected and Ho accepted.

To add benefits to this research, it can be concluded suggestions for the next researcher should in doing research using analysis of other profitability ratios, so it can be known which variable is more influential as an effort to improve profitability. In addition, the expansion of the sample and add to the research period by using longer time series data and using the latest data so that the results will be more accurate.

\section{REFERENCES}

James C Van Horne dan John M Wachowiez, Jr. (2008). Prinsip-Prinsip Manajemen Keuangan. Penerjemah Heru Sutojo. Jakarta: Salemba Empat.

Keown, A.J., Scott, D.F., Martin, J.D., Petty, J.W. (2010). Dasar-Dasar Manajemen Keuangan. Penerjemah Chaerul D. Djakman dan Dwi Sulistiorini. Jakarta: Salemba Empat.

Kieso, Donal E, Jery J, Weygant. (2013). Intermediate Accounting, 14th Edition, Andi\&Madcoms.

Mamduh M. Hanafi, Abdul Halim. (2007). Analisis Laporan Keuangan. Edisi 3. Yogyakarta: Sekolah Tinggi Ilmu Manajemen YPKN.\

Munawir, S. (2009). Analisa Laporan Keuangan, Edisi Ke-4. Yogyakarta: Liberti.

M. Munandar. (2007). Budgeting, Perencanaan Kerja Pengkoordinasian Kerja, Pengawasan Kerja, Edisi Pertama. Yogyakarta: BPFE.

Riduwan (2012). Metode dan Teknik Penyusunan Tesis. Bandung: Alfabeta.

Riyanto, Bambang (2011). Dasar-Dasar Manajemen Keuangan, Edisi Ke-4. Yogyakarta: BPFE.

Rudianto. (2009). Pengantar Akuntansi. Jakarta: Erlangga.

Sawir, Agnes (2010). Analisis Kinerja Keuangan dan Perencanaan Keuangan. Jakarta: PT. Gramedia Pustaka Utama. 